Ophthalmologe $2021 \cdot 118$ (Suppl 1):S81-S84 https://doi.org/10.1007/s00347-020-01281-5 Published online: 8 December 2020

(c) Springer Medizin Verlag GmbH, ein Teil von Springer Nature 2020

Sven Schnichels · Jens Martin Rohrbach • Tarek Bayyoud - Sebastian Thaler • Focke Ziemssen · José Hurst

Universitäts-Augenklinik Tübingen, Tübingen, Germany

\title{
Can SARS-CoV-2 infect the eye? An overview of the receptor status in ocular tissue
}

than SARS-CoV [13]. This effect is due to several changes in the gene and thus in the amino acid sequence of the spike protein compared to that of SARS-CoV [14]. The mammalian serine protease TMPRSS2 and the protease furin have been identified as relevant proteases for the interaction of the spike protein with ACE2 [15-17]. The ACE2 receptor is part of the renin-angiotensin system (RAS). This system plays a crucial role in the regulation of blood pressure as well as fluid and electrolyte homeostasis. It comprises dozens of angiotensin peptides and peptidases and at least six receptors, including ACE2 [18].

\section{Contradictions in the publications}

First of all, it must be said that until the outbreak of the current coronavirus pandemic, there was only scant evidence on expression of the receptor and the involved proteases in the eye. Recently, the number of publications has grown. Some of these publications are-at first glance-contradictory. Without discussing each individual publication here, there are various reasons for this: Firstly, the RNA and protein expression of a receptor very often differs, as could be determined in other, better-investigated ACE2-positive tissues (https://www.proteinatlas. org/ENSG00000130234-ACE2/tissue). Unfortunately, since that particular review is not up to date, no findings for the eye can be found here. The following homepage offers another review of ACE2 receptor expression and the possible proteases and enzymes involved: https://www.covid19cellatlas. org/. However, this website, too, does not offer a comprehensive overview of the literature. Furthermore, one must take into consideration the fact that the market is currently flooded with products for SARS-CoV-2 analysis. The preservation of receptors or proteases and the age of the tissue play a crucial role in analysis, i.e., the RNA or protein may already be degraded or masked in older or fixed tissue, which can lead to false-negative results. Therefore, the quality and validation of these new products is, unfortunately, often difficult to achieve, time consuming, and inadequate. All antibodies/primers used need to be validated concerning whether they recognize ACE1 (which is found in various segments of the eye) instead of ACE2 [18]. This contrasts with the requirement to obtain insight as rapidly as possible into whether SARSCov-2 is relevant in ophthalmology and poses a risk to medical personnel and other patients. Of course, interpretation and statistical analysis of data are also other points that need to be taken into account (see the dispute between several leading virologists and advisors to the German Federal Government/EU). But let us remain with this specific case: The question is: from which point on is expression deemed to be relevant? In order to be able to assess this, all findings-even those that initially appear to be contradictory-represent a benefit for research in the first instance and need to be validated in further studies. A metaanalysis/review on receptor status that 
analyzes and compares in detail the results from multiple studies is important here. A similar example that should be mentioned in this context is the first meta-analysis on viral status, which investigated all previous studies attempting to isolate live viruses or analyze ocular samples for viral RNA. Viral RNA was detected in only $5 \%$ of swabs taken from the ocular surface at each stage of the disease (9/178); in other words: $95 \%$ of samples did not yield viral RNA, and no viruses could be grown from any of the samples [19]. Therefore, in view of the low number of positive samples and the high number of negative samples, it is extremely unlikely that SARS-COV-2 is present on the ocular surface during coronavirus infection [20]. However, here again, the evidence needs to be viewed critically. The reason for the low number of positive samples could be false-negative PCR data due to sample degradation.

\section{Receptor status in the eye}

\section{Expression in corneal and conjunctival epithelial cells}

Expression of the ACE2 gene has been detected in corneal and conjunctival epithelial cells [21]. However, the amount of ACE2 expressed in conjunctival and corneal cells and tissue is lower than in heart and lung tissue [19]. Another study based on the transcriptome data detected the expression of mRNA for $A C E 2$ in corneal epithelium [22]. Again in that particular study, the amount of ACE2 expressed in the corneal epithelium was between five- and 20 -fold lower compared to the other tissues investigated (testis, small intestine, heart) [22]. Another transcriptome study detected ACE2 in a variety of corneal cells/tissues. $A C E 2$ was expressed primarily in limbal, conjunctival, and corneal epithelial cells [23]. The aforementioned serine protease TMPRSS2 and FURIN could not be detected either in tears or on corneal or conjunctival cells. However, it was demonstrated that some superficial conjunctival cells show co-expression of the TMPRSS2 and $A C E 2$ genes. The mean level of $A C E 2$ or TMPRSS2 mRNA expression in each ocular tissue was around $0.6 \%$, whereas the mean level of expression in most other tissues investigated (such as nasal cavity, lung parenchyma, ileum, colon, heart) was higher, at $1.2-1.4 \%$ [23]. The results of these two studies are in line with a previously published transcriptome analysis showing very low expression of $A C E 2$ in conjunctival samples [24].

Lange et al. recently demonstrated that ACE2 and TMPRSS2 mRNAs are not expressed at significant levels in conjunctival samples from healthy and diseased individuals. Antibodies were also unable to detect significant ACE2 protein expression [25].

These results contrast sharply with a recently published study by Zhang et al., which found strong ACE2 immune reactivity on the ocular surface [26]. ACE2 staining was particularly striking in the superficial conjunctival and corneal epithelium, as well as in the corneal limbus. In the corneal stroma, ACE2 staining was largely absent. ACE2 was also expressed in the corneal endothelium, whereby the intensity of staining was roughly the same as that in the corneal epithelium. Using western blot analysis, it was possible to confirm ACE2 expression. With regard to its subcellular localization, ACE2 was primarily detected in the cell membranes and cytoplasm, without nuclear staining. Moreover, TMPRSS2 was also detected in conjunctival and corneal samples, with a ubiquitous staining pattern compared to ACE2. TMPRSS2 staining was also weakly positive in some corneal stromal keratocytes. In the corneal limbus, TMPRSS2 showed intense expression in the multilayered epithelium. TMPRSS2 was found to be weak in the corneal stroma.

In their own investigations, the authors were also able to detect mRNA expression of ACE2 in fresh human cornea. This was on average 20-times stronger than in fresh human retina in the same patient (preliminarydata). Theywere unable to identify any relevant expression with detection using antibodies in older and freshly fixed samples, which is consistent with the study conducted in Freiburg, Germany, but not with the study in Baltimore, USA. These contradictory results in the literature as well as in the various methods now require further investigation. Therefore, the authors will analyze samples from the corneal bank in order to investigate receptor status in cultured tissue. Furthermore, they are currently comparing samples from patients who died of COVID-19 with healthy samples, to verify any possible differences here, too. In contrast, they were able to detect TMPRSS2 in the cornea using antibodies (preliminary data).

\section{Expression in the retina}

As mentioned before, the authors were able to demonstrate moderate ACE2 mRNA expression in unfixed retina. This is consistent with another study, which detected ACE2 by means of western blot of the human retina [27]. The previously mentioned study by Sungnak et al. was unable to demonstrate expression in the human retina, in contrast to the cornea [23]. However, the authors of that particular study themselves write that due to technical drop-out effects, the negative results should be viewed with caution, while the positive results are highly reliable [23]. ACE2 was also detected in rat and porcine retina at the mRNA and protein level $[28,29]$. Using in-situ hybridization, expression of the ACE2 gene was demonstrated in the inner granular layer, in this case in Müller cells. These results were confirmed by immunohistochemistry. Here, the ACE2 protein was localized in the soma of Müller cells in the inner nuclear layer, as well as in the Müller cell endfeet. What is interesting here is that expression is increased in diabetes. Furthermore, the ACE2 protein was localized to rods and cones [28]. As with all experimental animal studies, it goes without saying that these results need to be confirmed in human tissue.

Depending on the antibody used, the authors were also able to demonstrate expression at the protein level in older, fixed samples. Interestingly, these were the same eyes in which the cornea was negative. This positive staining in the retina is consistent with the previously described expression in the rat. They also observed expression in eyes of deceased coronavirus patients that is con- 
Ophthalmologe 2021 · 118 (Suppl 1):S81-S84 https://doi.org/10.1007/s00347-020-01281-5

(c) Springer Medizin Verlag GmbH, ein Teil von Springer Nature 2020

\section{S. Schnichels · J. M. Rohrbach · T. Bayyoud · S. Thaler · F. Ziemssen · J. Hurst}

\section{Can SARS-CoV-2 infect the eye? An overview of the receptor status in ocular tissue}

\section{Abstract}

Is the new coronavirus SARS-CoV-2 able to infect ocular tissue and thus poses a risk of infection through the tissue in addition to the risk of contact? This is the question that has occupied ophthalmologists since the beginning of the outbreak. In order to infect a certain type of tissue specific receptors for each virus and sometimes also coreceptors or other proteins must be present. The aim of this review was to summarize and reflect the current state of research with the help of the currently available literature as of 28 May 2020. At the time of the research, angiotensinconverting enzyme 2 (ACE2) was clearly identified as the receptor and transmembrane serine protease 2 (TMPRSS2) as the necessary protease to enable the infection of human cells with SARS-CoV-2. In the eye both ACE2 and TMPRSS2 are expressed, although sometimes very weakly and with varying degrees in different tissues. It is noteworthy that very different results were obtained with different methods. Several reasons can account for this effect: Firstly, the method of detection or preservation of the tissue, secondly, the possibly different expression of the tested tissue samples and thirdly, a possibly rapid loss of receptor expression post-mortem. Therefore, an infection of the eye seems possible, which has already been reported in various publications. The amount of virus or receptor expression necessary to cause an infection is not known. According to current state of knowledge the eye is not considered to be a high-risk tissue due to the low ACE2 and TMPRSS2 expression. Nevertheless, appropriate protective measures are necessary for both medical personnel and patients. In cases of corneal transplantation an infection of the donor tissue with SARS-CoV-2 must be excluded.

Keywords

COVID-19 - ACE2 receptor · TMPRSS2 $\cdot$ Retina . Cornea

\section{Kann SARS-CoV-2 das Auge infizieren? - Ein Überblick über den Rezeptorstatus in okularem Gewebe. English version}

\section{Zusammenfassung}

Kann das neue Coronavirus SARS-CoV-2 okulares Geweben infizieren und damit neben dem Kontaktrisiko ein Infektionsrisiko durch das Gewebe darstellen, ist die Frage, die die Augenheilkunde seit Beginn der Infektion beschäftigt. Um einen bestimmten Gewebetyp zu infizieren, muss jedes Virus seinen bestimmten Rezeptor und manchmal auch Korezeptoren oder andere Proteine vorfinden. Ziel dieser Übersichtsarbeit war es, mithilfe der aktuellen, zugänglichen Literatur (Stand 28.05.2020) den aktuellen Forschungsstatus zusammenzufassen und wiederzugeben. Zum Zeitpunkt der Recherche waren eindeutig ACE2 als Rezeptor und TMPRSS2 als notwendige Protease identifiziert, um die Infektion einer humanen
Zelle mit SARS-CoV-2 zu ermöglichen. Im Auge werden sowohl ACE2 als auch TMPRSS2 exprimiert, wenn auch teilweise sehr schwach und unterschiedlich schwach in verschiedenen Geweben. Beachtenswert ist, dass mit verschiedenen Methoden sehr unterschiedliche Ergebnisse erzielt wurden. Hierfür kommen mehrere Gründe infrage: zum einen die Methode der Detektion bzw. der Konservierung des Gewebes, zum anderen die möglicherweise unterschiedliche Expression der getesteten Gewebeproben, des Weiteren ein möglicherweise rascher Rezeptorexpressionsverlusts post mortem. Eine Infektion des Auges erscheint daher möglich, worüber auch schon in diversen Publikationen berichtet wurde. Welche
Virusmenge bzw. welche Rezeptorexpression notwendig ist, um eine Infektion zu ermöglichen, ist ungeklärt. Aufgrund der geringeren ACE2- und TMPRSS2-Expression ist das Auge nach aktuellem Wissenstand - aber nicht als Hochrisikogewebe anzusehen. Trotzdem sind entsprechende Schutzmaßnahmen sowohl für das medizinische Personal als auch für die Patienten notwendig. Bei Hornhauttransplantation ist eine Infektion des Spendergewebes mit SARS-Cov-2 auszuschließen.

Schlüsselwörter COVID-19 - ACE2-Rezeptor - TMPRSS2 - Retina . Kornea sistent with the expression described in humans, rats, and pigs [27-29]. Furthermore, expression appeared to be more pronounced in the samples from coronavirus patients compared to older human (COVID-19-negative) samples from the authors' archive (preliminary data). They also found, as in the cornea, TMPRSS2 expression in the retina. As already mentioned at the beginning of the article, the age of the sample, the method of preservation, and the selection of a wellvalidated antibody/primer really do appear to play a crucial role in the detec- tion of ACE2 expression. Alternatively, it may well be that coronavirus patients have stronger expression of ACE2 in the eye and, thus, this expression is detected first or more strongly with less-sensitive methods such as immunohistochemistry. This will form the subject of more advanced investigations.

\section{Other parts of the eye}

ACE2 has been detected in human aqueous humor [30], as well as in the ciliary body and vitreous body in porcine eyes [29].

\section{Summary}

This review of the literature to date, although doubtless not comprehensive, shows that both ACE2 and TMPRSS2 are expressed in the eye, albeit very weakly in some cases. Therefore, infection of the eye appears possible, as has already been reported in a number of publications. Further investigations are urgently needed on the precise oc- 
currence of infection in the eye as well as on the cause of the varying findings on expression in the different samples/ publications. In this context, the status of the ACE2 receptor in particular needs to be investigated.

\section{Conclusion}

Due to its low ACE2 and TMPRSS2 expression, the eye is not considered to represent high-risk tissue. Nevertheless, appropriate protective measures are required for both medical personnel and patients. In the case of corneal transplantation, SARS-CoV-2 infection of the donor tissue must be excluded.

\section{Corresponding address}

Dr. rer. nat. Sven Schnichels

Universitäts-Augenklinik Tübingen

Elfriede-Aulhorn-Str. 7, 72076 Tübingen,

Germany

sven.schnichels@med.uni-tuebingen.de

\section{Compliance with ethical guidelines}

Conflict of interest. S. Schnichels, J.M. Rohrbach, T. Bayyoud, S. Thaler, F. Ziemssen, and J. Hurst declare that they have no competing interests.

For this article no studies with human participants or animals were performed by any of the authors. All studies performed were in accordance with the ethical standards indicated in each case.

The supplement containing this article is not sponsored by industry.

\section{Literatur}

1. Belouzard S, Chu VC, Whittaker GR (2009) Activation of the SARS coronavirus spike protein via sequential proteolytic cleavage at two distinct sites. Proc Natl Acad Sci USA 106(14):5871-5876

2. Li $F$ (2016) Structure, function, and evolution of Coronavirus spike proteins. Annu Rev Virol 3(1):237-261

3. Wan Y et al (2020) Receptor recognition by the novel Coronavirus from Wuhan: an analysis based on decade-long structural studies of SARS Coronavirus. J Virol. https://doi.org/10.1128/jvi. 00127-20

4. Zhou P et al (2020) A pneumonia outbreak associated with a new coronavirus of probable bat origin. Nature 579(7798):270-273

5. Letko M, Marzi A, Munster V (2020) Functional assessment of cell entry and receptor usage for SARSCoV-2 and other lineage B betacoronaviruses. Nat Microbiol 5(4):562-569
6. Yan R et al (2020) Structural basis for the recognition of SARS-CoV-2 by full-length human ACE2. Science 367(6485):1444-1448

7. Lang J et al (2011) Inhibition of SARS pseudovirus cell entry by lactoferrin binding to heparan sulfate proteoglycans. Plos One 6(8):e23710

8. Simmons Getal (2013) Proteolytic activation of the SARS-coronavirus spike protein: cutting enzymes at the cutting edge of antiviral research. Antiviral Res 100(3):605-614

9. Matsuyama $S$ et al (2010) Efficient activation of the severe acute respiratory syndrome coronavirus spike protein by the transmembrane protease TMPRSS2. JVirol 84(24):12658-12664

10. Bertram S et al (2011) Cleavage and activation of the severe acute respiratory syndrome coronavirus spike protein by human airway trypsin-like protease. JVirol 85(24):13363-13372

11. LiW et al (2003) Angiotensin-converting enzyme 2 is a functional receptor for the SARS coronavirus. Nature 426(6965):450-454

12. Raj VS et al (2013) Dipeptidyl peptidase 4 is a functional receptor for the emerging human coronavirus-EMC. Nature 495(7440):251-254

13. WrappDetal (2020) Cryo-EM structure of the 2019$\mathrm{nCoV}$ spike in the prefusion conformation. Science 367(6483):1260-1263

14. Shang J et al (2020) Structural basis of receptor recognition by SARS-CoV-2. Nature 581(7807):221-224

15. Hoffmann M, Kleine-Weber H, Pohlmann S (2020) A multibasic cleavage site in the spike protein of SARS-coV-2 is essential for infection of human lung cells. Mol Cell 78(4):779-784e5

16. Hoffmann M et al (2020) SARS-CoV-2 cell entry depends on ACE2 and TMPRSS2 and is blocked by a clinically proven protease inhibitor. Cell 181(2):271-280e8

17. Matsuyama S et al (2020) Enhanced isolation of SARS-CoV-2 by TMPRSS2-expressing cells. Proc Natl Acad SciU SA 117(13):7001-7003

18. Holappa M, Vapaatalo H, Vaajanen A (2017) Many faces of renin-angiotensin system - focus on eye. Open Ophthalmol J11:122-142

19. Willcox MD et al (2020) The ocular surface, coronaviruses and COVID-19. Clin Exp Optom. https://doi.org/10.1111/cxo.13088

20. Xia J et al (2020) Evaluation of coronavirus in tears and conjunctival secretions of patients with SARS CoV-2 infection. J Med Virol. https://doi.org/10. 1002/jmv.25725

21. Liu L, Pan X, Shen W, Liu Z, Liu $Y$ et al (2004) Expression of SARS coronavirus $S$ protein functional receptor-Angiotensin-converting enzyme 2 in human cornea and conjunctiva. Chin Opthalmic Res 22:561-564

22. Sun Ket al (2020) Atlas of ACE2 gene expression in mammals reveals novel insights in transmisson of SARS-Cov-2. bioRxiv: p. 2020.03.30.015644

23. Sungnak $W$ et al (2020) SARS-CoV-2 entry factors are highly expressed in nasal epithelial cells together with innate immune genes. Nat Med 26(5):681-687

24. Xiang $M$ et al (2019) Comparative transcriptome analysis of human conjunctiva between normal and conjunctivochalasis persons by RNA sequencing. Exp Eye Res 184:38-47

25. Lange $C$ et al (2020) Expression of the COVID-19 receptor ACE2 in the human conjunctiva. J Med Virol. https://doi.org/10.1002/jmv.25981

26. Zhang BN et al (2020) Expression analysis of 2019 $\mathrm{nCoV}$ related ACE2 and TMPRSS2 in eye tissues. Zhonghua Yan Ke ZaZhi 56:E11
27. Senanayake P et al (2007) Angiotensin II and its receptor subtypes in the human retina. Invest Ophthalmol Vis Sci 48(7):3301-3311

28. Tikellis C et al (2004) Identification of angiotensin converting enzyme 2 in the rodent retina. Curr Eye Res 29(6):419-427

29. Luhtala $S$ et al (2009) Activities of angiotensinconverting enzymes ACE1 and ACE2 and inhibition by bioactive peptides in porcine ocular tissues. JOcul Pharmacol Ther 25(1):23-28

30. Holappa M, Valjakka J, Vaajanen A (2015) Angiotensin(1-7) and ACE2, "the hot spots" of Renin-Angiotensin system, detected in the human aqueous humor. Open Ophthalmol J 9:28-32 